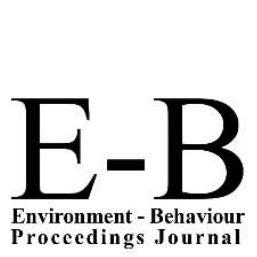

Proceedings Journal

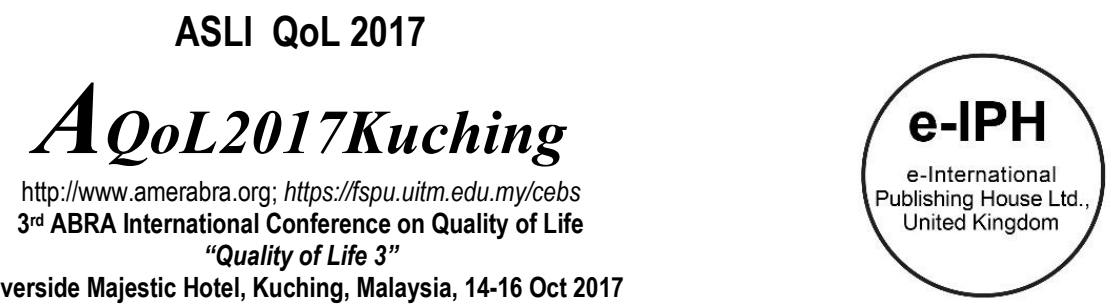

Riverside Majestic Hotel, Kuching, Malaysia, 14-16 Oct 2017

\title{
Land Registration of Titles at Stake: West and East Malaysia compared
}

\author{
Nuraisyah Chua Abdullah ${ }^{1}$, Ramzyzan Ramly ${ }^{2}$, Muhammad Izwan Ikhsan ${ }^{3}$ \\ ${ }^{1}$ Faculty of Law, Universiti Teknologi MARA, Shah Alam, 40450, Malaysia \\ 2 Faculty of Mechanical Engineering, Universiti Teknologi MARA, Shah Alam, 40450, Malaysia \\ ${ }^{3}$ Department of Law Enforcement, Vision College, Kelana Jaya, 47301, Malaysia \\ nuraisyah@salam.uitm.edu.my \\ Tel: 60355441083
}

\begin{abstract}
Registration of land title evidences an indefeasible ownership. However, many people have become victims of fraud. Due to the increase in fraud and the weaknesses of the registration system in the country, this study aims to provide solution to the problem. The paper highlights the controversy surrounding indefeasibility and the concept of federalism in the land administration systems in Malaysia. The electronic land systems and fraud prevention measures in the country are also analysed. While other jurisdictions have title assurance fund, it is not available in Malaysia. Thus, this paper suggests the tightening of the security measures to prevent fraud.
\end{abstract}

Keywords:fraud; land registration; indefeasibility; electronic systems

eISSN: 2398-4287○ 2017. The Authors. Published for AMER ABRA by e-International Publishing House, Ltd., UK. This is an open access article under the CC BYNCND license (http://creativecommons.org/licenses/by-nc-nd/4.0/). Peer-review under responsibility of AMER (Association of Malaysian Environment-Behaviour Researchers), ABRA (Association of Behavioural Researchers on Asians) and cE-Bs (Centre for Environment-Behaviour Studies), Faculty of Architecture, Planning \& Surveying, Universiti Teknologi MARA, Malaysia. https://doi.org/10.21834/e-bpj.v2i6.988

\subsection{Introduction}

Title registration fraud has increasingly become a primary concern in Malaysia and it greatly violate the right of the actual owner of the land. According to the statistics of the Department of Director General of Lands and Mines, there were 435 cases of title fraud and forgery reported from 2005 to April 2010, with Sabah recording the highest number of cases (86), followed by Selangor (56), Penang (47) and Kuala Lumpur (35). Among the most common occurrences is the falsification of the original issue document of title (IDT), identification card, signature, transfer form (Form 14A), power of attorney, court's order, as well as impersonation as a registered proprietor and estate agent. The same trend can be seen in the statistics published by the Royal Malaysian Police (RMP). It shows that from the period between 2005 and 2012, a total of 730 cases were reported and Sabah still recorded the most number of cases (154), followed by Selangor (106), Penang (55), Perak, (54) and Kuala Lumpur (53). More recently, from January to May 2016, the RMP received 151 reports involving land fraud with losses exceeding RM30 million. The number shows a sharp increase from 2015, which recorded 90 cases with losses amounting to RM20 million. According to the statistics, Selangor is the State where land fraud is most prevalent, with 43 cases followed by Johor with 33 cases (Hussin, 2016). Among the factors that lead to the increase of title fraud cases are the hikes in the property price making it attractive to the fraudsters, abandoned the land, and weaknesses in the registration system at the Land Office, which can be manipulated by criminals. Besides, the inherent weakness of the Malaysian land law on indefeasibility of title which fails to protect the original proprietor's interest when land has been transferred to innocent third party (bona fide purchaser for value) and the absence of State's title assurance fund to compensate the disgruntled original landowner

eISSN: 2398-4287@ 2017. The Authors. Published for AMER ABRA by e-International Publishing House, Ltd., UK. This is an open access article under the CC BYNCND license (http://creativecommons.org/licenses/by-nc-nd/4.0/). Peer-review under responsibility of AMER (Association of Malaysian Environment-Behaviour Researchers), ABRA (Association of Behavioural Researchers on Asians) and cE-Bs (Centre for Environment-Behaviour Studies), Faculty of Architecture, Planning \& Surveying, Universiti Teknologi MARA, Malaysia.

https://doi.org/10.21834/e-bpj.v2i6.988 
also contributes to the increase of title fraud incidences (Othman, 2008). Due to the increase in fraud and the weaknesses of the registration system in the country, this study aims to analyse this problem further and provide solution to the problem in view of the differences in the land administration system in Peninsular Malaysia, Sabah and Sarawak.

\subsection{Fraud in Title Registration: Modus Operandi}

Fraud in land title registration can take many forms and shapes, whether in paper based or electronic land registration systems. Corruption and abuse of authority for personal financial gain have been attributed as the root of evils (Abraham and Pane, 2016). Narcissism can also be inferred as a factor contributing to fraud. This is because a narcissist perceives the social life as a series of struggles for dominance. Thus, they can attack others even though there is no direct threat. They attack others only as a means to put them in a superior position by conquering, defrauding, or intimidating others (Abraham \& Pane, 2016). Forgery of the victim's signature is the most prevalent in the paper-based system. The crime is normally committed by a family member or a relative who copies the landowner on the instruments of dealing (such as transfer or charge). In some cases, the criminals also forge the signature of the witness who did not present to attest the execution of the instrument. In the computerised system of land registration, the usual practice is that the certifiers will sign documents on behalf of their clients digitally. Since individuals no longer sign documents, it would not be doable for the fraudster to forge the signature of the victim on the instrument. Nonetheless, to allow the certifier to sign the instrument on behalf of his client, the electronic system typically needs a client authorisation form to be completed and physically signed by the client and the certifier in front of a witness. Although the forgery of the victim's signature on the actual land title document is virtually impossible, the fraudster may still forge the signature in the client authorisation form. The potential for fraud by misleading the victim into signing documents in the electronic system is removed because the system does not require the signature of the land proprietor. Hence it would not be probable to carry out fraud by misleading the victim into signing the necessary instruments (Low, 2006).

In the paper-based framework of land dealing, lawyers can carry out fraud by forging the victim's signature. In the electronic system, solicitors who are also certifiers have access to the digital signature certificate to sign documents digitally on behalf of their clients. It is easier to commit fraud because the solicitor acting as certifier is not required to falsify the victim's signature. The solicitor can prepare the documents, sign it digitally and submit it electronically to the land office for the registration. It seems that the electronic system presents more opportunities for solicitor fraud to occur (Low, 2006).

Besides, identity fraud can also occur in the paper system. This usually happens when the lawyer is not observant in validating the identity of the person purporting to deal with the land. When the fraudster has access to the identity documents of the victim, it can be used by the criminal to commit fraud. Similarly, in the electronic system, identity fraud can be perpetrated if the solicitor is not vigilant in verifying the identity presented and simply accepts that the person he is dealing with is not a fraudster. In most cases, the criminals are someone known by the victim thus they can obtain the victim's identity documents easily. However, a stranger can still commit identity fraud if he steals the identity document of the victim. Thus, while computerisation of the land registration system makes monumental changes to the current conveyancing practices, the same people currently involved in frauds in the paper system will still be able to perpetrate fraud but by employing different approaches. The electronic system has distinctive attributes to the paper system that may give rise to new types of fraud. This primarily concerns the use of digital signature technology to replace the traditional handwritten signature (Low, 2006).

Besides, fraud by persons who have access to the digital signature can also happen. A fraudulent person with access to the electronic system can log in to the system using the id and password he obtained, prepares the necessary documentation, sign the instruments electronically, and submits the application electronically for registration. For instance, a law clerk in a law firm can commit fraud if he has access to the electronic system. Illegal use of the certifier's digital signature certificate to digitally sign documents is equivalent to the forgery of the handwritten signature. The only distinction is that in the paper-based system, given a samplehandwritten signature, anyone can forge the signature but the law enforcement agencies can conduct handwriting analysis to detect the forgery. In comparison, in the electronic land system, the fraudster cannot commit forgery unless he has access to the digital signature certificate and the password used to activate the digital signature certificate. However, once he has access to that information, fraud is easier to commit and harder to detect. Unlike the conventional handwritten signature, biometric or handwriting analysis is of no use to detect the forgery (Low, 2006).

\subsection{Management of Land Registration in Malaysia: Federalism Concept and Its Application}

Federalism is a framework whereby there are two levels of the government (Federal and States) which rule the same territory and people. Each level has areas of action in which it is autonomous, and there is some constitutional guarantee of the autonomy of each government in its sphere (Flippov et al., 2004). In Malaysia, historically, the Reid Commission was set up to make recommendations for the establishment of a strong central government with the states and settlements enjoying a measure of autonomy and with the consultation machinery between the two levels of government (Omar, 2012). One of the vital features of the Federal Constitution is the division of powers between the federal and state governments. Article 74(1) enables the Parliament to make laws for matters under the Federal List whereas Article 74(2) empowers the State Legislative Assemblies to enact laws for subjects that fall within the scope of the State List. According to the State List, land matters are one of the subjects within the competent jurisdiction of the State Legislature to legislate. Therefore, all land located within the state boundaries are vested in the state. Therefore, the States have the 
jurisdiction over the land. The constitutional arrangement also makes the State the supreme authority of the land administration, not the Federal Government (Awang, 2003).

Despite land matters being a subject under the State government's autonomy, the Parliament had used its power under Article 76 of the Constitution, for uniformity, to interfere in land matters. As a result, major land legislation, the National Land Code (hereinafter referred to as the NLCC) was enacted and came into force on 1st January 1966 for all the states of Peninsular Malaysia. The NLC was passed with the aim of establishing a unified land system concerning land tenure, registration of titles, and land dealings. The Code substituted forty-three different land statutes at the federal and state level. The NLC has extensively affected the land tenure system, land policies, and land development in the country. These changes were initiated with the object of attaining the national development objectives as provided under the different Malaysian development plans (Awang, 2003).

Besides, federal intervention in land matters is not restricted to its legislative capacity to make laws, but also via federal administrative agencies such as the National Land Council, the Office of the Director General of Lands and Mines, and the Regional Development Authority. The National Land Council must advise both the federal and state governments in respect of utilisation of land and any proposed legislation dealing with land or the administration of any such law. But, since the federal government has no executive functions and merely possesses an advisory capacity, it has no authority to put into effect its directions to the State (Awang, 2003).

In short, in Peninsular Malaysia, matters concerning registration of title are delegated by the State Land and Mines Department to the respective land offices at the district level. The Land Offices are primarily accountable for the collection of revenue, title registration, managing application for land dealings, changing of the condition of land use, subdivision, partition, or amalgamation of land or building and so on (Tan, 2013). The NLC provides limited powers to the Federal Director General of Land and Mines in matters relating to land administration. Reforms cannot be implemented in the States without the prior approval of the State Land Director and consent of the State Authority. These inabilities provide a limited scope for development of experts in land administration and developing a specific discipline in the land administration in the country. State Directors has the discretion to withhold information or refuse to cooperate with the Director General of Land and Mines. This situation will hamper the effective implementation and enforcement Federal Government policies and law that can promote uniformity within the country. However, the Director General of Land and Mines is not empowered to impose any punitive action on the State that refuses to comply with any policies or law (Ganason \& Maidin, 2010).

In Sarawak, the Land and Survey Department is a multi-functional organisation under the State Ministry of Planning and Resource Management. The core businesses of the Department involve surveying, land management (including land registry), planning, and valuation. Land matters in Sarawak are governed by the Sarawak Land Code 1958. Meanwhile, land administration organisational structure in Sabah share almost the same structure as Sarawak. All matters about land registration, administration of the cadastral survey and valuations of land premium in Sabah are entrusted to Lands and Surveys Department headed by the Director of Lands and Surveys. The Lands and Surveys Department is under the portfolio of the Chief Minister's Department through the office of the Secretary of Natural Resources. In Sabah, the Sabah Land Ordinance 1930 applies (Samsudin, 2011).

\subsection{Evolution of Registration Process in Peninsular Malaysia, Sabah, and Sarawak}

One aspect of comparison between land administration system in Peninsular Malaysia, Sabah, Sarawak, and foreign jurisdictions is the electronic land administration system employed by the respective jurisdiction. Information and Communication Technology (ICT) skills are currently of great interest to governments and business (Yusof et al., 2017), and land matters are not excluded. With the recent economic prosperity, Malaysia is going forward with its vision of becoming a technologically developed country by the year 2020 (Isa et al., 2017). Technology is changing and growing around the globe at a rate and pace never experienced before. The contribution of new technology to economic growth can only be realised when and if the new technology is widely adopted and used. Adoption itself results from a series of individual decisions to begin using the new technology, decisions which are often the result of a comparison between the uncertain benefits of the new invention and the unknown costs of implementing it (Takim et al., 2016). In the aspects of title registration and land dealing electronic system, in Peninsular Malaysia, e-Tanah system was first introduced in Penang before it was implemented in Negeri Sembilan and Melaka (Department of Director General of Lands and Mines, 2013). It was planned to be expanded nationwide, but to date, it has yet to materialise. The e-Tanah System is a computer system and a set of supporting rules and business practices within a legal framework that provide a reliable means of completing conveyancing and other land related transactions electronically. These arrangements are intended to replace the existing paper-based processes in the land administration of the State Land Registries. E-Tanah system was first introduced in Penang before it was implemented in Negeri Sembilan and Melaka (Department of Director General of Lands and Mines, 2013). e-Tanah provides an electronic environment to convert paper-based titles which are manually registered to electronic-based titles with bar-coded and electronic authentication of the Registrar's digital signature; and lodge instruments or submission of applications with Land Registries through single point of contact services and receive confirmation of their lodgment or submission and registration manually or by technological means (Ismail, 2012).

In the Peninsular States that have not implemented e-Tanah system, a system known as Secured Land Management System (SELAMAT) is in place. It was first implemented in 2010 in Temerloh Land Office and was extended to other land offices in Perak, Kelantan and Petaling Jaya in 2011 while in 2012, the system was implemented in Pahang, Perlis, Hulu Langat, Klang, Kuala Terengganu and Kulaijaya. SELAMAT was implemented in the whole of Pahang, Selangor, Johor, and Kedah in 2013 (Pemudah, 2014). In Putrajaya, SELAMAT was implemented on 1 December 2016 (Federal Territories Director of Lands and Mines Office, 2016). SELAMAT is the abbreviation of "Secured Land Management System" to prevent fraudulent land transactions, which was included in the computerised land registration system. It was first implemented in 2010 in Temerloh Land Office and was extended to other land 
offices in Perak, Kelantan and Petaling Jaya in 2011 while in 2012, the system was implemented in Pahang, Perlis, Hulu Langat, Klang, Kuala Terengganu and Kulaijaya. SELAMAT was implemented in the whole of Pahang, Selangor, Johor, and Kedah in 2013 (Pemudah, 2014). In Putrajaya, SELAMAT was implemented on 1 December 2016. This system serves to record fingerprints of landowners and solicitors to ensure proper and credible operation of land administration in line with the government policy to modernise land transaction in Malaysia. It is projected that the system will have a positive impact in addressing the issue of fraud in land administration and increase people's trust and confidence in the system (Klang Land Office, 2016). In this system, anyone dealing with the Registration Unit at the department of lands and mines and district land offices is required to use SELAMAT system whereby the fingerprints will be recorded to match the MYKAD information. The data will be kept in SELAMAT database and will be used for future dealings and to detect fraud and forgery (Berita Harian, 2013).

In Sabah, Land Dealing Electronic Submission System (LaDess) provides online digital submission and dealing system (Untong, 2015). The system is a collaboration between the Sabah Law Association (SLA) and the Department of Lands and Surveys, Sabah. Among the features of the system to ensure security of land dealing and to prevent fraud are such as law firms are required to prepare and print land dealing application forms, online land dealing status enquiry, SMS notification to customers on completed transactions, online printout of memo slip, online search on land owners' names and shares as well as registration of land clerks (Mu, 2016). Besides, LaDess is safe to use because it has a high level of security, in compliance with international standards and safe from hacking. Although there were attempts to by law firms to hack into the system and modify the information, it cannot be modified because the original document is still in the possession of the department (Oslan, 2016). Meanwhile, Sabah Land Information System (SALIS) which started in 1997 is a web-based system to integrate all Department of Lands and Surveys' digital textual, graphical and images onto a common platform. Among the early digital data integrated are - land titles textual information, land dealings information, land revenue information, graphical cadastral parcel, orthophotos. It later includes high resolution remotely sensed images land acquisition information, land value information, cadastral boundaries information etc. (Untong, 2015). The system includes Sabah Digital Cadastral Data Base (DCDB) which consists of more than 560,000 land parcels in the State (Untong, 2015). The comprehensive digital cadastral database (DCDB) which uses point entry methodology shall underpin the creation of a 'surveygrade' parcel fabric through homogeneous modelling, adjustment, and enhancement. The information-rich enterprise multi-purpose Cadastre info-structure is capable of supporting dynamic data mining, implementation of diversified land-based applications to serve specific individual for example land owner, user groups such as surveyors and developers and geospatial communities especially web/mobile users and so forth. With comprehensive land information of high integrity within reach shall expedite development program that involves land matters in that, an informed decision can be made in shorter time with reduced bottlenecks. The enterprise infostructure will substantially upgrade the Department's delivery system to become efficient, resourceful, and accurate in rendering services (Untong, 2014).

In Sarawak, the development of the Land and Survey Information System (LASIS) was initiated to include Title Registration System (TRS) that provides facilities for speedy processing and registration of land titles, strata titles and land dealings. In ensuring that LASIS system is effective and reliable, the Department improved it services through registration of land dealings within one day with automated e-mail notification to inform the legal firms instantly upon registration. Besides, the entirely integrated data sets allow the information to be made available on demand to facilitate intelligent analysis and reliable decision making (Land and Survey Department Sarawak, 2016). According to the information obtained from the Department, issuance of circular and policies on LASIS, use of standard prescribed forms and standard work process are vital in preventing fraud in the system. Regarding the security door access system of the server room, it is secured, and access is limited. On-site and off-site backup is also available, and title folios are equipped with security features to prevent forgery. The mirror image of the official register and owner's copy is also ensured. Besides, users of the system are given auto expiry password to control access to the system and prevent unauthorized access. Besides, to create awareness and detect abuse of the system, the audit is conducted from time to time. Another measure to prevent fraud is to involve multiple officers with specific limited roles in the electronic registration of land. For instance, the clerk is tasked to receive the application, make data entry, instrument allocation and the endorsement, and to print menu of the title folio. Then, a checker is responsible to make data verification and check verification reports and endorsement text for errors. After that, the application is forwarded to the Registrar who must update the case status and register the dealing. It will then be brought to the operation manager for system validation. If there is any error, the system will notify the Registrar of the error, and the Registrar must report using Fault Report Form for trouble shooting by Operation Manager to correct the error.

One of the most important security features of computerised land administration system is controlling access to the system. In Peninsular Malaysia, under the e-Tanah system, lawyers must register online through the e-Tanah portal where they will be given a User ID and Password. They can save and edit the NLC Forms before submission. They are also required to have an A3 printer to print out the NLC Forms. There is also A3 printer facilities at the Land Office for the public. It is pertinent to note that limiting access only to authorized users would make it easier for the system administrator to supervise and track the usage of the system as well as to keep up an audit trail of the users in the system. However, this would be more complicated to achieve in a system that is open for all to use (Ismail, 2012). Meanwhile, as for SELAMAT, anyone dealing with the Registration Unit at the Land Office is required to use SELAMAT system whereby their fingerprints will be recorded to match their MYKAD. The data will be kept in SELAMAT database and will be used for future dealings to detect fraud and forgery (Berita Harian, 2013).

In Sabah, the access to Land Dealings Electronic Submission System (LaDESS), access is reserved to legal firms (conveyances). As an additional security measure, LaDESS allows the firms to restrict user access to the system. For instance, the firm can manage its profile and specify access as follows: COMPADMIN - able to do all function and manage users, including suspending user 
accounts; SUPERUSER - able to prepare and submit dealing; and USER- able to prepare dealing only (Lands \& Survey Department Sabah \& Zuma Engineering, 2010).

In Sarawak, eLodgement module under e-LASIS enables law firms in Sarawak to do online submissions of the full range of instruments concerning land dealings. The system processes these submissions and will electronically lodge them if they are found to be in order. Like Sabah, the law firm needs to be registered in the online system. There are four (4) default Public User Groups for eLodgement. Each user group has been configured with specific access rights to eLodgement submission modules. When the company or law firm registers to the system, the system shall make a copy of the default user group settings and save it as specific company user groups. While the administrator can do all function and manage users, including suspending user accounts, the conveyancer can only prepare and submit dealing. The staff can prepare dealing only and do the prepayment of the legal firm (Sains, 2014).

Another security aspect of the computerised land administration system is the usage of the digital signature by the system. Malaysian e-Tanah system uses the appropriate technological framework for the use of electronic signatures similar to Singapore. Under e-Tanah environment, it appears that Land Registry envisages that the electronic signatures will be based on some form of Public Key Infrastructure. The e-Tanah system uses digital signatures in a PKI environment with DigiCert. To sign documents electronically, users of e-Tanah system will require a digital certificate, issued by DigiCert. Registration for a Digital Certificate require the following documents: identification document of applicant (identity card, passport, or work permit for foreigners); photocopy of front and back of identification document; and DigiCert digital personal certificate application form or for a Corporate DigiCert digital certificate, a corporate certificate application form (Ismail, 2012).

As for SELAMAT, it relies on biometric and fingerprint information. No mechanism regarding digital signature is available. In Sarawak's e-LASIS, digital certificates (DigiCert) is used to sign PDF documents and to authenticate users before the online submission for eLASIS applications (Sains, 2014). In Sabah, no digital signature is used under LaDESS as the physical presentation before the counter at Central Land Registry is still required (Lands \& Survey Department Sabah \& Zuma Engineering, 2010).

\subsection{Conclusion}

As shown above, the number of cases concerning title registration fraud in Malaysia is not showing any diminution. This sufficiently proves that the title registration system in Malaysia is susceptible to fraud. Apart from the inherent weaknesses of the land statutes on the issue of indefeasibility which leaves original proprietors uncompensated when their lands have passed on to the innocent third parties and the absence of State-guaranteed title assurance fund as a recourse of remedy for aggrieved original proprietors, as of date, not much can the land law system can do to protect them. In addition to that, the paper and electronic land registration systems have been proven to be vulnerable to fraud and new types of cyber crimes too. Although title insurance could be an option to indemnify against loss or damage arising out of defects in or upon the title to real property, it appears to be unsuitable mechanism in Malaysia at this point due to the low popularity, rate of subscription and general awareness of general insurance among Malaysians indicate the high possibility of low acceptance of title insurance, if it were to be introduced in Malaysia. On top of that, if title insurance is made compulsory, it will indicate non-confidence, insecurity and unreliability of the land administration system and gives a negative perception of the investors and the people about the government's ability to provide a safe and secure land management system.

Therefore, extra efforts need to be undertaken to ensure that the registration system is secure, safe, reliable and fraud-proof. This paper suggests that the security of the systems need to be tightened to diminish fraud. Audit trail needs to be conducted on the more frequent basis to detect any abnormalities in the systems. Besides, control on access to the system must also be tightly regulated. Specific officers should be allowed to do specific tasks in the system and involvement of multiple officers is a good way to prevent insider's fraud. As suggested by Yakob et al. (2016), it is important for the government to conduct relevant training for the officers involved and make improvements regarding its effectiveness. Additionally, the government should find ways to increase financial resources to employ more staff to carry out the relevant functions. Shibata et al. (2017) suggest that the government should review its crime prevention strategies to make it more effective and sustainable. An evidence-based approach is needed in implementing and supporting crime prevention strategies, especially concerning title registration fraud. According to Ismail et al. (2012), essentially there is a need for changes in the organisational culture in the aspects of physical changes, such as organisational structure, management systems, policies and procedures, action plans, short-term budgets or resource allocation, and information system. Besides, changes must also be made on the behaviour, such as values given to quality, excellence, communication, innovation, and employee participation. As of now, problems such as limited availability of the necessary equipment and facilities need to be resolved (Daud et al., 2016). Besides, strict registration requirements as applied in Sabah and Sarawak should be adopted in Peninsular Malaysia. Finally, it is also recommended that the physical appearance of the registered proprietor should be made compulsory. To date, 5th Schedule of NLC does not make the owner's appearance compulsory as he can sign the instruments in front of lawyer or land administrator. This is one of the weaknesses that need to be corrected by the land system. Besides, due to the application of indefeasibility concept in Peninsular Malaysia and Sarawak, it is also time to consider title assurance fund as compensation to the owner whose title has passed to the bona fide purchaser for value, without the fault of the owner. In Canada, Australia, and Singapore, the source for the fund is typically financed in part by levies and fees on dealings, caveats and withdrawal of caveats lodged under the land statute and shortfalls are met from the government's coffer. The need to incorporate the fund into the land system may in a way enhance integrity by having an accurate Register of Titles and provide additional efforts to combat fraud and forgery of documentation. Besides that, this effort shall also increase public and investor's confidence and support in the Malaysian land administration system (Ismail et al., 2013). Consumer knowledge and legal awareness also need to be raised (Ismail et al., 2016). This is an important 
measure so that the public can avoid becoming preys to title registration fraud. As implied by the study of Prayoga et al. (2016), intervention is a viable preventive mechanism to legal problems. This paper recommends that the government intervention to prevent fraud is of the utmost importance.

\section{Acknowledgements}

The authors thank the National Institute of Valuation for sponsoring this research under the National Real Estate Research Coordinator (NAPREC) fund and the Research Management Centre, Institute of Research Management \& Innovation (IRMI), Universiti Teknologi MARA for managing this grant under the project code 100-IRMI/GOV 16/6/2 (0022/2016).

\section{References}

Abraham, J., \& Pane, M.M. (2016). Conscientiousness and Collectivism as the Predictors of Shame and Guilt Proneness. Asian Journal of Quality of Life, AjQoL,1(3), Sep / Oct 2016 (p.1-9).

Abraham, J., \& Pane, M.M. (2016). The Role of Narcissism and Competitive Worldview in Predicting Environmental Apathy. Asian Journal of Quality of Life, AjQoL, Maiden, 1(1), May / June 2016 (p.35-42).

Awang, A. (2003). Conflict in the land law under the federation structure. In: International Convention on Urban Development \& Management (ICUDM 2003), 7-9 July 2003, Lada Complex, Langkawi, Kedah.

Berita Harian. (2013, September 12). Sistem SELAMAT bendung penipuan. Berita Harian, p 9.

Department of Director General of Lands and Mines. (1 April 2013). E-Tanah Project Group. Retrieved from https://www.jkptg.gov.my/ms/content/pasukan-projek-etanah-0

Daud, A.Z.C., Judd, J., Yau, M., \& Barnett, F. (2016). Barriers of Occupation-based Intervention. Asian Journal of Quality of Life, AjQoL, 1(4), Nov. / Dec. 2016 (p.1-10)

Federal Territories Director of Lands and Mines Office. (2016). Administrative direction. Retrieved from http://www.ptgwp.gov.my/index.php/pages/view/282

Flippov, M., Ordeshook, P.C., \& Shvetsova, O. (2004). Designing Federalism: A Theory of Self-Sustainable Federal Institutions. Cambridge: Cambridge University Press.

Ganason, A., \& Maidin, A.J. (2010). Land Administration System in Malaysia: Building Institutional and Organisational Capacity for Coordinating Land Administration between the Federal and State Authorities. Retrieved from http:/lifolio.ukm.my/Scripts/tinymce/plugins/ filemanager/files/2596/LAND_ADMINISTRATION_SYSTEM_IN_MALAYSIA_ANESH_AJMedit250320101.pdf

Harun, N., Hassim, J. \& Hamid, N. A. (2013). Penipuan, Rasuah dan Pencurian Maklumat Dalam Urus Niaga Tanah: Cabaran dan Penyelesaian. Jurnal Undangundang Malaysia KANUN, 23(1), 159-184.

Hussin, N. (2016, July 9). Tipu hartanah: 151 mangsa rugi RM30 juta. Utusan Malaysia.

Isa, K.A.M., Masuri, M.G., Azmi, A., \& Aziz, N.A.A. (2017). Behavioural Pattern of Mobile Phone Usage while Driving among Educated Young Adults in Klang Valley. Journal of ASIAN Behavioural Studies, jABs, 2(4),Jul / Sep 2017 (p.11-18).

Ismail, F.H., Chik, C.T., Muhammad, R., \& Yusoff, N.M. (2016). Practices Food Safety amongst Mobile Food Handlers in Shah Alam, Selangor. Asian Journal of Quality of Life, AjQoL, 1(4), Nov. / Dec. 2016 (p.31-40).

Ismail, F., Ahmad, N., Janipha, N.A.I., \& Ismail, R. (2017). The Behavioural Factors' Characteristics of Safety Culture. Journal of ASIAN Behavioural Studies, jABs, 2(4),Jul / Sep 2017 (p.91-98).

Ismail, M.S. (2012). Electronic land administration system in Malaysia: The need for new enabling provisions. Jurnal Pentadbiran Tanah, 2(1), 16-47.

Ismail, M.S., Ganason, A., \& Zakariah, Y. (2013). (2013) Land Administration System in Malaysia: The Torrens Assurance Fund. Jurnal Pentadbiran Tanah, 3(1), 53-60. Klang Land Office. (20 May 2016). Secured land management system. Retrieved from http://www2.selangor.gov.my/klang.php/pages/view/101

Lands and Surveys Department Sabah \& Zuma Engineering Sdn Bhd (2010).Land Dealings Electronic Submission System (LaDESS) User Instruction Version 1.0.retrieved from http://www.lands.sabah.gov.my/ladess/download/ladessUserlnstruction1.2.pdf

Land and Survey Department, Sarawak. (2016). Enhancing Service Delivery through LASIS. Retrieved from http://www.landsurvey.sarawak.gov.my/modules/web/pages.php?mod=webpage\&sub=page\&id=198

Low, R. (2006). Opportunities for fraud in an electronic land registration system: Fact or Fiction? ELaw Journal, 13, 225-253.

Maidin, A.J. \& Kadouf, H.A. (2010). Weaknesses in the registration of land dealings system in Malaysia: Suggestions for improvements for enhancing the system. [2010] 1 LNS(A) 1.

Mehdi K., \& Koorosh, A. (2015). Achievement to Environmental Components of Educational Spaces for Iranian Trainable Children with Intellectual Disability. Procedia Social and Behavioral Sciences, 201, 9-18. 
Mettam, G. R., \& Adams, L. B. (1999). How to prepare an electronic version of your article. In B. S. Jones \& R. Z. Smith (Eds.), Introduction to the electronic age (pp. 281-304). New York: E-Publishing Inc.

Mu, P. (1 December 2016). Sabah Lands and Surveys Dept launches enhanced version of LaDESS version 2.1. New Sabah Times. Retrieved from http://www.newsabahtimes.com.my/nstweb/fullstory/11543

Muda, S., Jamal, J.A., Jamarudi, E.M.M., Rahman, R.A. \& Misnan, N. (2013) Legal Protections for Registered Proprietor under the National Land Code 1965: Original Landowner vs. Bona Fide Purchaser. International Academic Conference (IAC) 2013, UiTM Terengganu.

Nathan, P.K. (2002) Nightmare for registered owners of landed property [2002] CLJ xxiii.

Omar, R. N. A. R. (2012). A historical perspective of federalism in Malaysia and its effects on the current system of federalism.International Journal of Business, Economics, and Law, 1, 125-129.

Oslan, S. (1 December 2016).Tiada lagi borang permohonan tanah secara manual selepas 1 Jun 2017. Utusan Borneo. Retrieved from Retrieved from https://www.pressreader.com/malaysia/utusan-borneo sabah/20161201/283119953534265

Othman, S. (2008). Penipuan dalam Urusan Tanah: Isu dan Penyelesaian. Jurnal INSTUN, 1(2),4-5.

Pemudah. (2014). Annual Report 2014. Retrieved from http://www.pemudah.gov.my/documents/10124/37722/Annual_Report2014_BI.pdf

Prayoga, T., Pea, A.G., \& Pradipto, Y.D. (2016). Efficacy and Decisional Balance to Intervene. Asian Journal of Quality of Life, AjQoL,1(3), September/October 2016 (p.11-19).

Sains. (2014). LASIS eLodgement. Retrieved from http://www.elasis.sarawak.gov.my/eLodgementuserguide/\#Chapter 1/Introduction.htm\%3FTocPath\%3DChapter\%25201\%2520-\%2520System $\% 25200$ verview\%7C

Samsudin, S. (2011). A Review of Organizational Arrangements in Malaysia Land Administration System towards Good Governance: Issues and Challenges. Paper presented at the FIG Working Week 2011 Bridging the Gap between Cultures Marrakech, Morocco, 18-22 May 2011.

Shibata, S., Hanyu, K., Asakawa, T., Shimada, T., \& Omata, K. (2017). People's Crime Perception, and Attitude toward Community Crime Prevention Activities in Japan. Journal of ASIAN Behavioural Studies, jABs, 2(2), Jan / Mar 2017 (p.57-66).

Takim, R., Harris, M., \& Nawawi, A.H. (2016). Building Information Modeling: Quality of life. Asian Journal of Quality of Life, AjQoL, Maiden, 1(1), May / June 2016 (p.111).

Tan, L.C. (2013). Towards developing a three-dimensional cadaster for three-dimensional property rights in Malaysia. PhD thesis, Faculty of Geoinformation and Real Estate, Universiti Teknologi Malaysia (Unpublished).

Teo, K.S. (2002). Demise of Deferred Indefeasibility under the Malaysian Torrens System?Singapore Journal of Legal Studies, 403-408

Untong, S. (2014). Development of Multi-Purpose Cadastre in Sabah. Paper presented at the FIG Congress 2014: Engaging the Challenges, Enhancing the Relevance Kuala Lumpur, Malaysia, 16 - 21 June 2014.

Untong, S. (2015). Geo-Cadastre In Land Administration: Sabah's Experience. Paper presented at the Geosmart Asia 2015, 29 September - 1 October 2015, Kuala Lumpur.

Bishop, K., \& Said, I., (2017). Challenges of Participatory Qualitative Research in a Malaysian and Australian Hospital.Asian Journal of Environment-Behaviour Studies, 2(4), 1-11.

Yakob, H., Yusof, F., \& Hamdan, H. (2016). Measuring Effectiveness of Planning and Control. Asian Journal of Behavioural Studies, AjBeS 1(4), Nov./ Dec. 2016 (p.1123)

Yusof, M.M., Hashim, N., \& Tobi, S.N.M. (2017). Level of ICT usage and perceived attributes among academicians. Journal of ASIAN Behavioural Studies, jABs, 2(2), Jan / Mar 2017 (p.37-45) 